\title{
Foreword to the Special Issue Dedicated to Rafail Kalmanovich Gordin
}

\author{
Vladimir Dotsenko ${ }^{1} \cdot$ Alexander Shen $^{2} \cdot$ Mark Spivakovsky $^{3}$ \\ Published online: 10 July 2019 \\ (c) Institute for Mathematical Sciences (IMS), Stony Brook University, NY 2019
}

This issue, as well as the next one, is dedicated to Rafail Kalmanovich Gordin on the occasion of his seventieth birthday. Perhaps the clearest explanation of Gordin's role in high school maths education in Moscow that the reader can get is offered by the contents of these issues. When, anticipating the anniversary celebrations, we started contacting his former high school students with a suggestion to submit papers to the special issue of AMJ, the number of excellent quality submissions was so high that even after thorough peer review ensuring compliance with the AMJ standards we had enough research papers for two issues! The only thing that was missing was a foreword offering some context. Upon our request, it was provided by Alexander Shen, an expert in theoretical computer science from the University of Montpellier, himself a teacher of mathematics high schools in Moscow for many years, a colleague and a friend of Gordin's. The only thing that remains for us, two of many grateful former students of Gordin, is to join in wishing Rafail Kalmanovich many happy returns of the day.

Vladimir Dotsenko, Mark Spivakovsky

Vladimir Arnold wrote in his recollections of Andrei Kolmogorov

...when ...I compared him with a mountain climber who made first ascents, contrasting him to Israel Gelfand whose work I compared with the building of highways, both men were offended. '...Why, you don't think I am capable of creating general theories?' said Andrei Nikolaevich. 'Why, you think I can't solve difficult problems?' added Israel Moiseevich.

However, both first ascents and constructions of highways are infrequent enough; without drivers, highways get abandoned, without fans of mountaneering, conquered peaks become mere legends. Most users of maths encounter it in school, and their

\footnotetext{
$凶 \quad$ Vladimir Dotsenko vtimorin@hse.ru

1 Trinity College Dublin, the University of Dublin (TCD), Dublin, Ireland

2 LIRMM, Montpellier, France

3 Université Paul Sabatier Toulouse, Toulouse, France
} 
maths teacher becomes the face of mathematics (depending on their luck, human or not).

Rafail Kalmanovich Gordin became a high school teacher against his wishes. During his time as a high school student, he participated in maths olympiads and summer schools; once admitted to a physics and mathematics boarding school of the Novosibirsk State University, he decided to not go there (despite his parents' trying to convince him otherwise) and stayed in his hometown (Novogrudok, Belarus). Following that, he studied at the Mathematics Department of the Belarus State University in Minsk, and graduated from there in 1970 .

As was the case with many Jewish students in the Soviet Union at the time, he was not admitted to graduate school, and was directed to the Ministry of Education for allocation (there was a requirement to spend a certain time after graduation at a workplace somewhat randomly allocated by the authorities). As a result, he spent three years as a teacher in an institute of technology in his hometown. After that, he managed to move to Moscow following his wife and tried to find work as a computer programmer. Despite a reference from a prominent mathematician and computer scientist Alexander Kronrod (who knew Gordin through a family acquaintance), it proved to be a hard task.

After a certain time of unsuccessful search, Gordin said that if there was no other choice he would not mind teaching in a high school, perhaps Kronrod could be his reference for that? To Gordin's great surprise, Kronrod said that it was no mean feat, and the first step would be a serious maths exam. However, the exam went well, and Kronrod together with Nikolai Konstantinov (a key figure in the system of mathematics high schools in Moscow) found a job for Gordin, first a part-time gig in High School 179 and then, since 1974 till the present day, a full-time position in High School 57, a placement enjoyed equally by his students and by himself. Books and teaching materials he created over the years, including an online database of plane geometry problems zadachi.mccme.ru, are well known among Russian high school students and their teachers.

Gordin probably would have become a good researcher in maths or a computer programmer, 'but God deemed otherwise', and so he managed to make a difference as a teacher in a mathematics high school. He was lucky to have taught a great number of talented and capable students, and most of them remained grateful to him, both for maths lessons and for (anything but intrusive) lessons of life. When last year his 70th birthday celebration was being prepared, an idea had emerged to prepare, in addition to presents and greetings of all forms, a special issue featuring articles by his former students. As usual, it was impossible to produce it on time, but now this offering from grateful former students and colleagues is finally ready.

Many happy returns of the day!

Alexander Shen

Этот и следующий выпуск журнала посвящён Рафаилу Калмановичу Гордину к его семидесятилетию. Возможно, что содержание этих выпусков предложит читателю наиболее внятное объяснение роли Р.К. Гордина в школьном математическом образовании в Москве. Когда мы, в преддверии юбилея, стали связываться с его бывшими учениками 
с вопросом, не хотят ли они подать статью в специальный выпуск, статей очень высокого уровня на самые разные математические темы было подано столько, что даже после тщательной работы рецензентов, сузившей круг авторов в соответствии с общими стандартами журнала, статей оказалось достаточно для двух выпусков! Единственное, чего не хватало, это короткого вступительного текста, создающего контекст. По нашей просьбе такой текст написал Александр Шень, эксперт по теоретической информатике университета Монпелье, сам преподаватель московских математических школ с большим стажем, коллега и друг Гордина. Нам - двоим из огромного числа благодарных учеников остаётся лишь присоединиться к поздравлениям.

Владимир Доценко, Марк Спиваковский

Вспоминая о Колмогорове, Арнольд рассказывал:

...когда я... сравнил Андрея Николаевича с альпинистом-первовосходителем, противопоставляя его Израилю Моисеевичу Гельфанду, деятельность которого я сравнил с прокладкой шоссе, то обиделись оба. «...Что же, Вы не считаете меня способным создавать общие теории?» - сказал Андрей Николаевич. «Что же, Вы думаете, я не способен решать трудные задачи?» — добавил Израиль Моисеевич.

Но первовосходителей и строителей шоссе мало - если не будет желающих ездить по дорогам и взбираться на вершины, дороги будут заброшены, а покоренные вершины станут легендой. Большин ство встречается с математикой в школе, и лицом математики (увы, не всегда человеческим) для них становится учитель.

Рафаил Калманович Гордин стал школьным учителем против своей воли. Школьником он участвовал в олимпиадах и летних школах; будучи принят в физико-математический интернат в академгородке (Новосибирск), он поступать туда не стал (несмотря на настойчивые советы родителей) и окончил школу в родном городе (Новогрудок, Беларусь). После этого он поступил на матфак Белорусского государственного университета в Минске, который и окончил в 1970 году.

В аспирантуру его (как еврея) не взяли, и распределили в Министерство просвещения (в советское время после окончания ВУЗа требовалось отработать определённое время в указанном месте). Он вернулся в Новогрудок, где и проработал три года преподавателем математики в техникуме. Потом он переехал в Москву (у жены была такая возможность), и пытался найти работу программиста. Несмотря на рекомендации А. С. Кронрода (знакомого семьи), это оказалось сложно.

В конце концов Гордин сказал, что по крайности готов даже в школе поработать - не может ли Кронрод его рекомендовать? Кронрод ответил, что дело сложное, сначала надо как следует проэкзаменовать по математике (чем немало удивил кандидата). Экзамен прошёл успешно, и Кронрод и Н.Н. Константинов договорились о месте для Гордина 
сначала в 179 школе (с небольшой нагрузкой), а потом и в 57-й, где Гордин работает с 1974 года и до сих пор - к удовольствию и школьников, и его самого. Написанные им книги и материалы (включая задачи для электронного сборника задач по геометрии, zadachi.mccme.ru) хорошо известны российским школьникам и учителям.

Наверное, Гордин был бы хорошим математиком или программистом — «но Бог судил иное», и именно в качестве учителя математики в математических классах ему удалось “make the difference”, как говорят поанглийски. Более чем за сорок лет работы ему посчастливилось учить множество талантливых и просто способных школьников, и большинство из них остались ему благодарными и за уроки математики, и за (совершенно не навязчивые!) уроки жизни. Когда в прошлом году зашла речь о празднования 70-летия, помимо разных других подарков и посланий, его ученики решили в качестве подготовить юбилейный номер журнала. Как обычно, к юбилею не успели - но сейчас приношение от благодарных учеников и коллег разных лет готово.

Многая лета!

Александр Шень

Publisher's Note Springer Nature remains neutral with regard to jurisdictional claims in published maps and institutional affiliations. 